\title{
Analisis Kontrastif Persepsi Mahasiswa terhadap Psikologi Pembelajaran dan Implikasinya terhadap Peran Guru Suatu Studi Deskriptif Kualitatif terhadap Mahasiswa Murni dan Mahasiswa Bekerja pada Program Studi Pendidikan Anak Usia Dini di Universitas Al Azhar Indonesia
}

\author{
Fidesrinur \\ Program Studi Pendidikan Anak Usia Dini, Fakultas Psikologi dan Pendidikan, \\ Universitas Al Azhar Indonesia, Jl.Sisingamangaraja, Jakarta 12110 \\ E-mail: fideza@uai.ac.id
}

\begin{abstract}
Abstrak - Pertumbuhan yang cepat dalam Pendidikan Anak Usia Dini (PAUD) ini belum diiringi oleh ketersediaan dan kemampuan guru yang memadai. Untuk itu Perguruan Tinggi Keguruan perlu mepersiapkan calon guru yang siap mengajar sesuai dengan perkembangan ilmu terkini berdasarkan konteks pembelajaran yang dihadapi. Perbedaan latar belakang mahasiswa program studi PAUD antara mahasiswa yang berlatar belakang guru dan mahasiswa murni merupakan suatu fenomena yang menarik untuk dikaji guna memperoleh kesamaan dan perbedaan persepsi dalam menyikapi filosofi pembelajaran baik secara teori maupun praktek. Hasil kajian menunjukkan bahwa mahasiswa yang berlatar belakang guru lebih fleksibel dalam menerapkan pendekatan pembelajaran sesuai konteksnya, sedangkan mahasiswa murni lebih berorientasi pada siswa sebagaimana tuntutan perkembangan teori belajar saat ini. Perbedaan ini menunjukkan bahwa mahasiswa harus dibekali praktek pembelajaran lebih banyak dengan berbagai konteks sehingga memberikan fleksibilitas dalam pembelajaran.
\end{abstract}

Abstract - The growth of Early Childhood Education (ECE) not yet supported by qualified teacher that makes early childhood education quality are low. As ECE educator producer, ECE Department of Al Azhar Indonesia University should take role on preparing teacher's candidate to become well inform both in theoretical and practical perspectives based on contextual teaching. The differences of student's background between transferred student and fresh student become a phenomenon toward their own teaching perspectives. The research findings show that transferred students are more flexible than fresh student in teaching where most of fresh student thinking based on the latest theory studied based on books. The implication of the study is that the fresh student should have experiences long enough in teaching with various students background. The experiences with various students background might combine the essence of theory read by the student based on contextual practices.

Keywords - Teacher's Belief on Education Philosophy, University Student's Background, Teacher's Behavior Continuum, Teacher's Skill

\section{PENDAHULUAN}

\subsection{Latar Belakang Permasalahan}

$\mathrm{P}$ erlindungan atas hak-hak anak, khususnya yang terkait dengan pendidikan anak usia dini menjadi pusat perhatian dunia. Kepedulian atau perhatian ini antara lain terlihat dalam bentuk kesepakatan-kepakatan atau deklarasi yang melibatkan sebagian besar negara-negera di dunia termasuk Indonesia. Dalam Deklarasi Dakkar (2002) antara lain disepakati bahwa: (1) Memperluas dan memperbaiki keseluruhan perawatan dan pendidikan anak usia dini, terutama bagi anak-anak yang sangat rawan \& kurang beruntung; (2) Menjamin bahwa menjelang tahun 2015 semua anak mempunyai akses dan menyelesaikan pendidikan dasar yang bebas \& wajib dengan kualitas baik; (3) Menjamin bahwa 
kebutuhan belajar semua manusia muda dan orang dewasa terpenuhi melalui akses yang adil pada program-program belajar dan kecakapan hidup (life skills) yang sesuai; (4) Mencapai perbaikan 50\% pada tingkat keaksaraan orang dewasa menjelang tahun 2015, terutama bagi kaum perempuan; (5) Menghapus disparitas gender dalam pendidikan dasar dan menengah menjelang tahun 2005 dan mencapai persamaan gender dalam pendidikan menjelang tahun 2015; (6) Memperbaiki semua aspek kualitas pendidikan dan menjamin keunggulannya, sehingga hasil-hasil belajar yang diakui dan terukur dapat diraih oleh semua, terutama dalam keaksaraan, angka \&kecakapan hidup (life skills) yang penting. Akses terhadap pelayanan pendidikan dan perawatan merupakan dua hal penting bagi PAUD dalam deklarasi ini.

Selanjutnya beberapa kesepakatan untuk keselarasan perhatian terhadap anak antara lain juga terdapat dalam: (1) Convention on The Right of the Child (1989) tentang pemenuhan hak-hak dasar anak; (2) World Fit for Children (2002): mencanangkan kehidupan yang sehat, pendidikan yang berkualitas perlindungan terhadap aniaya, exploitasi dan kekerasan serta memerangi HIV/AIDS. Memberikan kesempatan yang lebih luas bagi anak untuk berpartisipasi dalam pengambilan \& pemenuhan hak-hak dasar anak; dan (3) United Nations Millenium Declaration-8 September 2000 tentang perlunya nilai-nilai dasar yang bersifat universal yang harus ditanamkan pada anak-anak;

Kesepakatan-kesepakatan yang telah dikemukakan di atas pada dasarnya juga telah termaktub dalam Pembukaan UUD 1945 yaitu, " ........ melindungi segenap bangsa Indonesia dan seluruh tumpah darah Indonesia dan untuk memajukan kesejahteraan umum, mencerdaskan kehidupan bangsa". Selanjutnya dalam amandemen UUD 1945, Pasal 28b secara khusus dikemukakan bahwa setiap anak berhak atas kelangsungan hidup, tumbuh dan berkembang serta berhak atas perlindungan dari kekerasan dan diskriminasi. Walaupun perhatian terhadap anak telah menjadi bagian yang penting dalam UUD 1945 namun dalam pelaksanaannya pendidikan anak belum mendapat perhatian sebagai mana yang diharapkan. Terbukti baru pada tahun 1989 diadakan Wajib belajar 9 Tahun yaitu pendidikan SD dan SLTP sehingga anak usia prasekolah belum mendapat prioritas yang memadai.
Pada tahun 2002 baru diterbitkan Undang-Undang Perlindungan Anak No. 23 tahun 2002 yaitu bahwa setiap anak berhak untuk dapat hidup, tumbuh, berkembang, dan berpartisipasi secara wajar sesuai dengan harkat dan martabat kemanusiaan, serta mendapat perlindungan dari kekerasan dan diskriminasi. Selanjutnya setahun kemudian Undang-Undang Sisdiknas pada Pasal 1 (14) No. 20 Tahun 2003 PAUD menjelaskan bahwa Pendidikan Anak Usia Dini (PAUD) adalah suatu upaya pembinaan yang ditujukan kepada anak sejak lahir sampai dengan usia enam tahun yang dilakukan melalui pemberian rangsangan pendidikan untuk membantu pertumbuhan dan perkembangan jasmani dan rohani agar anak memiliki kesiapan dalam memasuki pendidikan lebih lanjut. Usia dini (lahir -6 tahun) merupakan masa perkembangan dan pertumbuhan yang sangat menentukan bagi anak di masa depannya atau disebut juga masa keemasan (the golden age) namun sekaligus periode yang sangat kritis yang menentukan tahap pertumbuhan dan perkembangan anak selanjutnya.

Perhatian mulai tumbuh dengan beredarnya hasil Penelitian di bidang Neorologi: Osbon, White, Bloom ditemukan bahwa (1) perkembangan intelektual Usia 0 s/d 4 tahun mencapai 50\%; 4 s/d 8 tahun mencapai $80 \% ; 8$ s/d 18 tahun mencapai $100 \%$; (2) perkembangan fisik 0 tahun mencapai 25\% ; 8 tahun mencapai 90\%; 12 tahun mencapai $100 \%$. Data ini menunjukkan bahwa anggapan pendidikan baru bisa dimulai setelah usia SD tidak benar, bahkan pendidikan yang dimulai pada usia TK (4-6 th) pun sebenarnya sudah terlambat.

Disamping itu perkembangan pengetahuan, kebijakan dan program tentang pengasuhan dan pendidikan anak usia dini usia di bawah enam tahun yang belum sepenuhnya dapat menyentuh masyarakat yang kurang beruntung yang berjumlah jutaan orang sehingga tidak mencapai perkembangan sesuai dengan potensi yang dimilikinya karena kemiskinan, kekurangan gizi, kesehatan yang rendah dan pengasuhan yang tidak tepat.

Hasil-hasil penelitian para ahli tentang anak usia dini menunjukkan bahwa intervensi terhadap anak usia dini sangat penting. Investasi pada usia dini sangat berguna sebagai langkah awal dalam pengembangan pendidikan utamanya pendidikan dasar dan menengah, dan merupakan cara yang penting agar terhindar dari dampak pada sosial 
ekonomi yang kurang menguntungkan. Apabila suatu negara melakukan investasi pada anak usia dini, negara tersebut telah mempersiapkan tahapan pembelajaran dan produktifitas melalui akses ke sekolah, meningkatkan hasil pembelajaran dan keuntungan dari pendidikan yang tinggi.

Ada beberapa dampak pendidikan anak usia dini terhadap kehidupan anak yaitu: (1) Kesiapan anak memasuki pendidikan lebih lanjut, (2) Mengurangi Angka mengulang kelas, (3) Mengurangi Angka putus Sekolah (Do), (4) Mempercepat Pencapaian Wajib belajar, (5) Meningkatkan Mutu Pendidikan,

(6) Mengurangi Angka buta Huruf muda, (7) Memperbaiki Derajat kesehatan \& gizi anak balita, dan (8) Meningkatkan Indeks Pembangunan Manusia (IPM).

Lima tahun menjelang 2015, sebelum batas yang ditentukan untuk pendidikan untuk semua (EFA), banyak Negara dan kelompok regional yang berupaya untuk mengembangkan berbagai cara guna mencapai tujuan tersebut. Dewan SEAMEO dan konferensi yang ke-45 nya yang dilaksanakan pada Januari 2010, bersepakat untuk memberikan komitmen pada tujuan pendidikan untuk semua, khususnya pada tujuan EFA yang pertama yaitu perluasan dan peningkatan pengasuhan dan pendidikan anak usia dini secara komprehensif khusunya bagi anak-anak yang kurang beruntung. Dalam forum tersebut telah disepakati Dewan Menteri SEAMEO berbagi pengalaman dalam ECCE yang menjadi pokok perhatian dalam peran dan pencapaian yang signifikan dalam ECCE guna memberikan keyakinan dan peningkatan kualitas pendidikan dasar.

Deklarasi dan kesepakatan-kesepakatan negaranegara terhadap pentingnya pendidikan anak usia dini telah mendorong perhatian pemerintah terhadap pendidikan anak usia dini. Perhatian yang besar dari pemerintah ini telah mendorong percepatan dan perluasan PAUD di seluruh wilayah Indonesia. Namun permasalahan pembelajaran anak usia dini yang relatif baru berkembang ini mengalami berbagai kendala dalam proses pembelajaran terutama dalam kaitannya dengan teori yang dipelajari dengan praktek pembelajaran yang dilakukan di kelas.

Mahasiswa Lembaga Pendidikan Tinggi Keguruan (LPTK), khususnya mahasiswa PAUD memegang peranan yang strategis dalam mewujudkan kualitas anak di masa yang akan datang. Pembelajaran teori dan praktek merupakan isu utama dalam penanaman sikap dan perilaku guru dalam mengajar kelak. Permasalahan teori dan praktek selalu menjadi isu yang mempengaruhi proses belajar mengajar di sekolah termasuk di Pendidikan Anak Usia Dini (PAUD). Banyak sekolah yang mengklaim mengembangkan kurikulum dengan falsafah tertentu seperti Montessori, Regio Emilia, Bankstreet dan lain sebagainya, namun dalam kenyataannya pembelajaran yang dikembangkan tidak seperti iklan yang dipromosikan tersebut. Permasalahan yang sama juga terjadi dalam pendidikan Anak di Singapore dimana filosofi pembelajaran tidak sepenuhnya terjadi dalam pembelajaran yang sesungguhnya. Filosofi pendidikan telah menjadi komoditi bisnis dalam mempromosikan sekolah sehingga tujuan pendidikan mulai kehilangan arah dalam upaya mencerdaskan bangsa.

Pandangan terhadap filosofi pendidikan adalah suatu keyakinan pendidik tentang bagaimana seorang anak belajar dan atas keyakinan pembelajaran tersebut selanjutnya pembelajaran direncanakan, dilaksanakan dan dievaluasi. Filosofi pembelajaran merupakan pandangan pembelajaran dari berbagai ahli yang telah dikembangkan berdasarkan penelitian yang berulang-ulang sehingga menjadi suatu keyakinan yang mendasari pembelajaran. Oleh sebab itu filosofi tidak hanya dipelajari sebagai pengetahuan atau kognitif saja, tetapi merupakan motif pembelajaran yang dikembangkan oleh pendidik PAUD.

Motif pembelajaran merupakan dorongan sikap dan kepribadian pendidik dalam memahami suatu proses pembelajaran yang tidak hanya mencerdaskan anak tetapi membentuk sikap dan perilaku yang utuh dalam membelajarkan anak. Filosofi pembelajaran dapat dilihat dari peran guru dalam proses pembelajaran yaitu bagaimana guru memperlakukan siswa dalam pembelajaran Perlakuan tersebut dapat dilihat bagaimana guru memposisikan murid dalam pembelajaran, apakah pembelajaran berorientasi murid atau berorientasi guru atau bahkan berada diantara keduanya.

Peran guru merupakan akumulasi pengalaman guru atau calon guru dalam proses pembelajaran, baik proses pembelajaran pada saat ia belajar maupun pengalaman yang diperoleh selama mengikuti teoriteori pembelajaran yang dikembangkan ilmuwan. Dalam kaitan itu maka mahasiswa murni dan mahasiswa bekerja merupakan dua sosok mahasiswa yang berbeda latar belakang. Mahasiswa murni adalah mahasiswa yang belum 
mempunyai pengalaman dalam pembelajaran di kelas. Pengetahuan mahasiswa murni tentang filosofi pembelajaran masih berupa pengetahuan yang dipelajari secara teori di kelas. Sementara itu mahasiswa yang telah bekerja sebagai guru PAUD telah mempunyai pengalaman dalam mengajar di kelas, kemudian memperoleh pengetahuan tentang filosofi pembelajaran di bangku perkuliahan.

Pengalaman yang berbeda antara mahasiswa murni dan mahasiswa bekerja ini akan memberikan implikasi yang berbeda dalam mengembangkan filosofi pembelajaran. Filosofi pembelajaran ini tidak hanya akan berdampak pada tata cara pembelajaran yang dikembangkan pendidik PAUD, lebih dari itu filosofi ini akan mempengaruhi tata cara proses belajar mengajar di kelas yang juga akan mempengaruhi cara belajar anak sepanjang hayatnya. Hasil penelitian menunjukkan bahwa perkembangan anak pada 0-6 tahun (usia emas) merupakan fondasi dalam memperkuat anak dalam mencapai keberhasilannya dalam pembelajaran yang berarti untuk kehidupan anak yang lebih baik.

Selain itu, juga ditemukan bahwa tidak semua pengetahuan yang diperoleh oleh mahasiswa di bangku perkuliahan di aplikasikan di kelas. Ada beberapa hal yang menyebabkan tidak digunakannya pengetahuan yang diperoleh di bangku perkuliahan yaitu antara lain: sarana dan prasarana yang kurang lengkap, pola pembelajaran yang telah terbangun di sekolah sehingga sulit untuk berubah, dan tentu saja kemauan dari guru untuk berinovasi yang rendah.

Berdasarkan pemikiran di atas maka penelitian dengan judul Analisis Kontrastif Perbedaan Persepsi Mahasiswa terhadap Falsafah Pembelajaran dan Implikasinya terhadap Peran Guru dalam Pembelajaran: Suatu Studi Kualitatif terhadap Mahasiswa Murni dan Mahasiswa Bekerja pada Program Studi Pendidikan Anak Usia Dini UAI dapat memberikan informasi tentang falsafah pembelajaran calon pendidik anak usia dini serta implikasinya dalam proses pembelajaran yang akan terjadi.

\subsection{Masalah Penelitian}

Pembelajaran yang dikembangkan di Indonesia selama ini lebih berorientasi pada pengetahuan atau kognitif. Pembelajaran yang dikembangkan berorientasi kognitif ini mengakibatkan pengembangan afeksi dan psikomotorik anak terabaikan, sehingga anak hanya mampu menyampaikan tanpa memahami maknanya. Selain itu pembelajaran anak usia dini seharusnya bersifat holistik dan berorientasi pada anak, dimana seluruh inderanya harus dilibatkan dalam proses pembelajaran. Semua permasalahan ini bermuara pada filosofi pembelajaran yang diyakini oleh pendidik PAUD. Filosofi merupakan faktor penggerak utama dalam menentukan pilihan-pilihan pembelajaran yang akan dikembangkan pendidik PAUD dalam proses belajar mengajar di kelas. Semua ini akan diwujudkan dalam peran guru dalam proses belajar mengajar.

Sementara itu hasil penelitian menunjukkan bahwa kemampuan guru dalam mengajar pada umumnya hanya berdasarkan bagaimana ia diajar pada saat belajar ketimbang mengajar dengan cara yang diajarkan saat ini. Fenomena ini menunjukkan bahwa adanya kegagalan dalam melakukan tranformasi pembelajaran berdasarkan filosofi pembelajaran yang berkembang saat ini.

\subsection{Pembatasan masalah}

Masalah penelitian ini dibatasi pada perbedaan persepsi mahasiswa terhadap falsafah pembelajaran dan implikasinya terhadap proses belajar mengajar. Perbedaan persepsi dengan latar belakang berbeda yaitu mahasiswa murni dan mahasiswa bekerja akan memberikan pemahaman yang berbeda sesuai dengan pengalaman yang diperoleh mahasiswa. Mahasiswa murni hanya mempunyai pengalaman secara teori sementara itu mahasiswa bekerja disamping mempunyai pengalaman secara teori yang dipelajari juga melakukan praktek langsung yang dilakukan mahasiswa bekerja. Pengalaman yang berbeda-beda ini akan memberikan implikasi yang berbeda pula dalam perannya dalam proses belajar mengajar.

\subsection{Perumusan masalah}

Sehubungan dengan pembatasan masalah penelitian di atas, maka perumusan masalah dapat dikemukakan sebagai berikut:

(1) Apakah terdapat perbedaan persepsi mahasiswa murni dan mahasiswa bekerja terhadap pendekatan pembelajaran?

(2) Apakah terdapat perbedaan persepsi mahasiswa murni dan mahasiswa bekerja terhadap praktek pembelajaran?

(3) Apakah yang melatar belakangi perbedaan persepsi mahasiswa murni dan mahasiswa bekerja terhadap pembelajaran di PAUD? 


\subsection{Signifikansi Masalah}

Pembelajaran yang berorientasi kognitif merupakan implikasi dari falsafah yang dianut oleh pendidik yang ditenggarai sebagai faktor utama gagalnya pendidikan di Indonesia. Falsafah pembelajaran yang dianut pendidik tidak hanya akan berdampak pada hasil pembelajaran semata tetapi juga berdampak pada tata cara perlakuan pendidikan terhadap anak yang selanjutnya akan berpengaruh pada bagaimana cara anak belajar. Artinya cara pembelajaran yang dikembangkan oleh pendidik akan mempengaruhi cara belajar anak sepanjang hayatnya. Dengan mengetahui hasil yang diperoleh dari latar belakang mahasiswa yang murni dan mahasiswa bekerja atau yang telah mengajar memberikan informasi yang berguna dalam memecahkan peran guru dalam proses pembelajaran.

\section{KERANGKA TEORI}

\subsection{Hakekat Pembelajaran}

Guru mempunyai suatu kesempatan untuk meningkatkan kualitas siswanya melalui pendidikan. Dalam perannya, seorang guru mempunyai kekuasaan untuk menciptakan suatu komunitas peserta didik dalam kelasnya setiap hari. Hakikat dari suatu pendidikan adalah pembelajaran sepanjang hayat. Pendidikan sepanjang hayat artinya pendidikan yang dilakukan terjadi pada setiap helaan nafas manusia. Untuk itu pembelajaran pada diri manusia tidak mengenal batas-batas waktu dan tempat pembelajaran. Dalam kaitan itu pula maka pendidikan formal seyogyanya merupakan satu kesatuan yang tidak terpisahkan dengan pendidikan nonformal dan informal untuk mencapai kemandirian dalam belajar. Dengan demikian hasil belajar diharapkan dapat membelajarkan peserta didik secara mandiri sehingga mereka dapat menguasai pengetahuan, keterampilan dan sikap tanpa tergantung kepada guru.

Pada setiap tahapan pendidikan oleh peserta didik adalah suatu aktivitas untuk menanamkan kemampuan peserta didik untuk secara mandiri dapat belajar sesuai dengan tingkat pendidikannya. Kemandirian belajar merupakan tujuan akhir dari suatu proses belajar mengajar yang dilakukan oleh guru dan murid yang dalam dunia pendidikan disebut juga instruksional atau pengajaran. Menurut Reigeluth (2009:06-07) instruksional adalah segala sesuatu yang dilakukan bertujuan untuk memfasilitasi pembelajaran. Memfasilitasi pembelajaran artinya berupaya untuk mengetahui tentang keseluruhan pengajaran yaitu apa hasil pengajaran yang diharapkan? bagaimana proses pencapaian hasil pengajaran tersebut didisain dan dibangun? bagaimana mengimplementasikannya? dan bagaimana hasil pengajaran dievaluasi? bagaimana hasil pembelajaran diukur? apa konten yang akan diajarkan? bagaimana peserta didik belajar? dan bagaimana interelasi diantara semua hal tersebut diatas dengan pengajaran yang dilakukan oleh guru?

Instruksional sebagai suatu sistem pembelajaran menurut Cruickshank (2006:03) ditentukan oleh faktor-faktor yang mempengaruhi bagaimana guru mengajar. Faktor-faktor tersebut antara lain: (1) karakteristik diri, (2) pengalaman dan persiapan dalam pendidikan, (3) konteks pengajaran. Pertama karakteristik diri meliputi gender, usia, pengalaman, kepribadian dan keyakinan. Kedua, pengalaman dan persiapan dalam pendidikan yaitu (1) bagaimana kita diajar sebelumnya, (2) bagaimana cara yang kita inginkan untuk diajari, (3) bagaimana keinginan kita dalam mengajar, (4) latar belakang mata ajar, dan (5) persiapan pengajaran yang dilakukan. Ketiga, konteks pengajaran yaitu (1) keadaan peserta didik, (2) kelas/besaran ukuran kelas, (3) materi dan peralatan, (4) waktu, (5) tujuan pengajaran, dan (6) tujuan pendidikan nasional.

Upaya untuk memfasilitasi pembelajaran dengan mempetimbangkan faktor-faktor yang mempengaruhi guru dalam pengajaran, maka guru menetapkan konstruksi instruksional. Menurut Reigeluth (2009:28-29) Konstruksi instruksional meliputi latihan, demonstrasi, kolaborasi, analogi, pengajaran berbasis permasalahan, urutan dari hal yang sederhana kepada hal yang kompleks dan sebagainya. Sedangkan efektivitas konstruksi instruksional adalah pencapaian atau penguasaan adalah hasil belajar dengan kriteria yang telah ditetapkan. Dalam kaitan penguasaan pembelajaran tersebut Davies (1981:22) mengemukakan bahwa penguasaan pembelajaran berkaitan dengan realisasi tujuan pembelajaran yang telah ditetapkan untuk tugas tertentu. Harapan tersebut dikemukakan dalam bentuk kriteria 90/90/90 yaitu 90 prosen menguasai 90 prosen tujuan dalam 90 prosen waktu yang disediakan. Namun yang paling penting dari semua itu bukanlah prosentasenya akan tetapi mahasiswa berhasil dalam sebagian besar waktunya yang digunakan dalam belajar. 
Untuk itu tujuan pembelajaran harus berguna bagi peserta didiknya. Bagi siswa tujuan pembelajaran tidak hanya untuk mempelajari sesuatu tetapi segala sesuatu yang telah dikuasai oleh mahasiswa pantas untuk dimiliki dan bermanfaat bagi mereka. Pembelajaran harus bermakna bagi tugas-tugas tertentu yang akan diembannya, pekerjaan yang akan dihadapi dan peran yang akan dimainkannya sebagai guru kelak dikemudian hari. Apabila tugastugas yang diberikan tidak berfaedah, berarti bahwa mahasiswa belum mempelajari sesuatu apapun.

\subsection{Pendekatan pada Pendidikan Anak Usia Dini}

Pandangan terhadap anak selalu mengalami perubahan dari generasi kegenerasi lainnya. Perubahan pendangan terhadap anak ini juga berpengaruh terhadap tata cara memperlakukan anak dalam kehidupan sehari-hari. Pengalaman sehari-hari ini juga merupakan dasar bagi pengembangan anak di dalam keluarga. Sejalan dengan berkembangnya pengetahuan dan kebutuhan dalam pengembangan anak maka pendidikan di rumah makin dirasakan tidak mencukupi lagi. Keterbatasan pendidikan anak dalam keluarga ini makin dirasakan bersamaan dengan tekanan kehidupan ekonomi keluarga sehingga waktu untuk mengurus pendidikan sulit dilakukan. Pendidikan yang dikembangkan secara formal ini diikuti dengan penelitian tentang bagaimana anak belajar.

Pendekatan atau falsafah pendidikan merupakan landasan pikir seseorang dalam mengembangkan pembelajaran. Semua aktivitas yang dikembangkan oleh guru dalam interaksi belajar mengajar dilandasi oleh suatu keyakinan atau pola pikir tentang bagaimana anak belajar. Filosofi atau falsafah pembelajaran merupakan keyakinan yang dimiliki oleh guru dalam pendidikan. Selanjutnya falsafah ini menjadi dasar dalam pengembangan pembelajaran. Pengetahuan dan teknologi serta masyarakat dalam pendidikan dan pengasuhan anak makin berkembang bersamaan dengan perkembangan falsafah pendidikan itu sendiri.

Menurut Moore (2005::xv) tidak seorangpun dapat menyangkal bahwa permasalahan guru dan keterampilan mereka akan berdampak pada prestasi siswa. Untuk membuat dampak yang positif, guru harus mempunyai pemahaman yang kuat dan mendalam tentang prinsip-prinsip pembelajaran yang digunakan dalam pembelajaran yang efektif dan tentu saja bagaimana cara guru menerapkan prinsi-prinsip tersebut di kelas. Guru yang efektif adalah seseorang yang secara terus menerus merefleksikan bagaimana teori-teori dan pelaksanaannya dalam keputusan-keputusan berdasarkan konsepsi teori dan praktek berdampak pada anak.

Banyak teori belajar yang mengilhami falsafah pendidikan seperti behaviorisme, kognitivisme, konstruktivisme dan lain-lain. Masing-masing teori belajar tersebut mempunyai landasan sendirisendiri dalam memandang anak sebagai subjek didik dan kemudian akan diwujudkan dalam peran yang dimainkan oleh guru dalam proses belajar mengajar. Menurut Neisworth (2005:186) Behaviorisme adalah suatu filosofi yang dikenal di seluruh dunia, sebagai suatu sistem kepercayaan yang berkaitan dengan kealamian dan penyebabpenyebab terjadinya perilaku dan perkembangan. Perilaku dan perkembangan anak dapat dianalisis scara ilmiah dan dapat ditingkatkan melalui pengembangan lingkungan. Behaviorisme berpandangan bahwa perilaku manusia bersifat alami dan oleh karenanya perilaku menurut hukum tertentu.

Pada tahun 1950-an BF Skinner seorang psikolog Havard University melakukan kajian tentang perilaku yang dapat diamati yang dikenal dengan behaviorisme. Ia tertarik pada kesukarelaan dalam berperilaku, seperti mempelajari keterampilan baru daripada perilaku refleksif. Sementara itu Pavlov terkenal dengan penelitian terhadap air liur anjing. Ia mendemonstrasikan bahwa pola perilaku organism dapat dibentuk dengan memberi penguatan, atau hadiah sehingga menghasilkan respon yang diharapkan terhadap lingkungan. Skinner mendasari teorinya dengan teori penguatan dengan cara meneliti merpati kemudian dengan hasil penelitian itu mendasari prosedur tersebut sesuai dengan manusia. Hasil-hasil penelitian ini mempengaruhi program pembelajaran, teknik dalam langkah-langkah pengajaran pada tingkat kinerja tertentu yang diharapkan. Penelitian Skinner ini berbeda dengan penelitian sebelumnya karena cara kerjanya sangat logis, mempunyai ketepatan yang tinggi, secara langsung diarahkan untuk meningkatkan disain pengajaran.

Behaviorisme menolak spekulasi tentang apa yang terjadi secara internal pada saat pembelajaran berlangsung. Ahli ini hanya berlandaskan pada perilaku yang dapat diamati. Hasilnya, mereka lebih memilih tugas-tugas pembelajaran yang bersifat sederhana karena behaviorisme mempunyai 
keterbatasan dalam mengaplikasikan disain pengajaran pada keterampilan tingkat tinggi. Misalnya, behavioris enggan menyimpulkan bagaimana peserta didik menyimpulkan informasi, walaupun dalam melakukan dengan mengetahui informasi tersebut membantunya untuk mendisain pengajaran yang dapat mengembangkan kemampuan pengambilan keputusan. Prinsipprinsip behavioris pada saat ini digunakan dalam pengajaran berbasis computer dan pendidikan berbasis web.

Dalam kaitan itu Skinner dalam Brewer (2007:06) pembelajaran sebagai suatu pengontrolan dengan sistem penguatan dan hukuman. Teori behavioris menurut Kami dalam Roopnarine (2005:22) memandang anak sebagai penerima pengetahuan yang bersifat pasif yang diperoleh melalui imitasi dan latihan dan diinternalisasikan melalui proses penguatan positif dan penguatan negatif.

Pada pertengahan abad ke 20, kognitivis memberikan kontribusi pada teori belajar dan disain pengajaran dengan menciptakan model tentang bagaimana peserta didik menerima, memproses, dan memanipulasi informasi. Kognitivisme berdasarkan hasil kerja Jean Piaget ahli psikologi Swiss. Ahli Psikologi kognitif mengekplorasi proses mental individual yang digunakan dalam merespon lingkungan mereka.

Kognitivisme membahas tentang bagaimana orang berpikir, memecahkan masalah, dan mengambil keputusan. Apabila behavioris secara sederhana menyatakan praktek memperkuat respon terhadap stimulus. Sedangkan kognitivis menciptakan model mental tentang memori jangka pendek dan memori jangka panjang. Informasi baru disimpan dalam memori jangka pendek, dan apabila "dilatih" secara terus menerus pada waktunya akan tersimpan dalam memori jangka panjang. Jika informasi tidak dilatih atau diulang-ulang, lama-kelamaan ia akan hilang dari memori jangka pendek. Peserta didik kemudian mengkombinasikan informasi dan keterampilan dalam memori jangka panjang untuk mengembangkan strategi kognitif atau keterampilan yang terkait dengan tugas-tugas yang kompleks. Kognitivisme mempunyai persepsi yang luas dalam pembelajaran daripada yang dikaji dalam behaviorisme: peserta didik kurang tergantung pada panduan guru dan lebih mengacu pada strategi kognitif dalam menggunakan ketersediaan sumber-sumber belajar.
Konstruktivisme adalah suatu gerakan yang berada di luar keyakinan ahli kognitivisme. Perspektif konstruktivisme mendorong keterlibatan peserta didik dalam pengalaman yang bermakna sebagai esensi dari pengalaman belajar. Konstruktivis menekankan pada siswa untuk mengkreasi interpretasinya tentang informasi-informasi yang ada di dunia. Keyakinan ini bertolak belakang dengan perspektif behaviorisme maupun kognitif bahwa pikiran dapat "dimapping" oleh pengajar. Konstruktivis memberikan alasan bahwa penempatan pembelajaran sesuai dengan pengalaman peserta didik dan tujuan pembelajaran bukan untuk menjejali mereka dengan informasi tetapi untuk menciptakan situasi sehingga peserta didik dapat menginterpretasikan informasi sesuai dengan pemahaman peserta didik sendiri. Peran pengajar bukan untuk menjejalkan fakta-fakta tetapi memberikan kesempatan kepada peserta didik dengan cara menggabungkan pengetahuan. Konstruktivis berkeyakinan bahwa pembelajaran dapat terjadi secara efektif apabila peserta didik dilibatkan dalam tugas-tugas otentik yang terkait dengan kebermaknaannya sesuai dengan konteks, belajar sambil melakukan.

Teori konstruktivisme menurut Jean Peaget dalam Brewer (2007:08) bahwa anak membangun pengetahuannya melalui interaksi dengan lingkungan. Anak bukanlah penerima pengetahuan yang pasif tetapi ia secara aktif bekerja dan mengorganisasikan pengalaman ke dalam struktur mental yang lebih kompleks. Menurut Roopnarine (2005:22) Padangan konstruktivis berasumsi bahwa anak mengkonstruksi pengetahuannya melalui pengalaman-pengalaman. Anak merupakan arsitek yang aktif dalam pembelajaran. Teori konstruktivis berarti membentuk pemikiran tidak hanya melengkapi pemikiran.

Psikologi sosial merupakan satu tradisi baru dalam kajian belajar dan pembelajaran. Ahli psikologi sosial mengkaji efek organisasi sosial kelas dalam pembelajaran. Bagaimanakah struktur kelompok belajar: belajar mandiri, kelompok kecil, atau kelas secara keseluruhan? Apakah struktur otoritas: seberapa besar kontrol terhadap peserta didik dalam aktivitas mereka? Apa bentuk struktur system reward, apakah dalam bentuk kerjasama atau dalam bentuk kompetisi?

Peneliti seperti Robert Slavin mengambil posisi bahwa pembelajaran kerjasama lebih efektif dan menguntungkan secara sosial dari pada kompetitif dan bersifat indvidualistik. Slavin mengembangkan 
seperangkat teknik pembelajaran kooperatif dengan mengembangkan prinsip-prinsip kerjasama kelompok kecil, pengajaran yang dikontrol peserta didik sendiri, dan reward berdasarkan kepada pencapaian kelompok.

Terkait dengan itu Dodge dkk (2002:173) mengemukakan bahwa pembelajaran pada anak usia dini penuh dengan kontradiksi. Kontradiksi dalam pembelajaran tersebut ada yang bersifat tenang, dinamis, mudah diprediksi, tetapi penuh dengan kejutan; bersifat aktif dan pengalaman langsung, tetapi pembelajaran juga dalam ketenangan dan reflektif. Kontradiksi ini merupakan rentangan pendekatan pembelajaran. Pembelajaran tersebut terkait pula dengan gaya belajar anak. Selanjutnya Dodge (2002:31) mengemukakan bahwa setiap orang termasuk anak mempunyai cara-cara yang menyenangkan bagi mereka dalam belajar. Sebagian anak senang belajar secara visual, sebagian lainnya belajar dengan lebih baik dengan menyimak, sementara anak lainnya harus mengalami langsung secara fisik untuk memahaminya. Gaya belajar satu tidak lebih baik dengan gaya belajar yang lainnya, perbedaannya hanya merupakan cara seorang anak dapat belajar lebih baik.

Tujuan pembelajaran teori-teori pembelajaran adalah untuk mempersiapkan mahasiswa kelak menjadi guru yang efektif. Guru yang efektif dilandasi oleh penguasaan pengetahuan dan keterampilan yang terdiri atas pengajaran/ pengetahuan pedagogi (bagaimananya) untuk mengajarkan konten/subjek pengetahuan (keapaannya) kepada anak (kesiapaannya). Menurut Leng (2005:86) konsep "repertoire" merupakan sesuatu yang bersifat kompleks dalam bentuk berbagai tugas dalam profesi mengajar dalam lingkungan sekolah. Sebagai seorang guru, ia mempunyai spesifikasi pekerjaan yang luas. Pekerjaan tidak dapat diukur, dikuantifikasi atau dikompensasikan dalam bentuk uang. Ada lima kawasan inti dalam penguasaan "repertoire" pengetahuan dan keterampilan yang harus dioptimumkan guna menciptakan kondisi yang optimal bagi pembelajaran dan kinerja siswa. Penguasaan atau "repertoire" tersebut adalah pengetahuan tentang diri, proses, konten, ilmu didik anak, kebiasaan sekolah, dan siswa dan gaya belajarnya.

Pertanyaan yang selalu muncul menjadi kontroversi adalah pendekatan pembelajaran mana yang lebih baik. Dalam kaitan itu maka dari teori-teori pendidikan yang dikemukakan terlihat bahwa pendapat tentang pembelajaran diantara masingmasing pendekatan pembelajaran tetapi juga terjadi antar pendekatan pembelajaran. Artinya masingmasing pendekatan mempunyai kekuatan dan kelemahannya, tergantung pada apa tujuan pembelajaran yang akan dikembangkan. Untuk itu Brophy dalam Cruichkshach (2006:89) mengemukakan bahwa ada beberapa macam pembelajaran yang bersifat kualitatif, masingmasing pembelajaran tersebut mempunyai seperangkat pilihan latar pembelajaran, kegiatankegiatan pembelajaran dan teknik-teknik pembelajaran yang digunakan. Perbedaaanperbedaan ini mengingatkan kita bahwa berbagai macam bentuk pembelajaran memiliki tata cara tersendiri dalam pengajaran.

Dari berbagai pendekatan pembelajaran yang dikemukakan sebelumnya maka Cruichkshach (2006:91-92) mengemukakan bahwa sebagian besar pengajaran berdasarkan kepada tiga pendekatan pembelajaran utama yaitu teori kognitif, humanistik, dan behavioristik. Ketiga pendekatan pembelajaran tersebut dalam penggunaannya ditentukan oleh tugas pembelajaran, karakteristik dan kebutuhan peserta didik.

Pertama, pendekatan kognitif tertarik pada bagaimana pengetahuan dikuasai oleh peserta didik. Kajian kognitif terpusat pada pemrosesan informasi dan kebermaknaan pembelajaran. Pemrosesan informasi terkait ditinjau dari fenomena perhatian, ingatan jangka pendek, ingatan jangka panjang, mengingat dan melupakan. Pembelajaran bermakna terfokus pada bagaimana peserta didik dapat belajar dengan baik guna memahami dan mengerti dan menggunakan informasi. Praktek pendidikan yang diusulkan oleh pendekatan kognitif antara lain meliputi pembelajaran reseptif, pembelajaran otentik, pijakan, pembelajaran resiprokal, dan pemecahan masalah.

Kedua, Pendekatan humanistik tertarik pada perkembangan personal peserta didik, yaitu tentang diri, perasaan, sikap, dan nilai-nilai yang diperoleh. Pendekatan humanistik ini lebih terfokus pada pembelajaran akademik utama tentang pembelajaran tentang diri dan orang lain. Dalam kaitan itu pula maka pendekatan humanistik menyarankan pendidikan dan pengajaran perlu mengembangkan pengetahuan tentang diri dan untuk meningkatkan konsep diri peserta didik. Praktek pembelajaran dengan pendekatan humanistik ini meliputi pembelajaran invitational, 
klarifikasi moral, pendidikan moral dan karakter, dan pendidikan multi etnis.

Ketiga, pendekatan behaviorisme tertarik mengkaji bagaimana lingkungan diubah dan dimanipulasi guna mengubah perilaku sesuai dengan yang diharapkan. Pendekatan behaviorisme mengkaji kontak, classical conditioning, operan conditioning, dan social atau observasi pembelajaran sebagai alat untuk perubahan perilaku. Praktek pendidikan yang dikembangkan oleh pendekatan behaviorisme antara lain adalah pengajaran terprogram, pengajaran berbatuan komputer, pembelajaran penguasaan, pembelajaran ketelitian, dan aplikasi analisis perilaku.

\subsection{Keterampilan Guru Efektif}

Guru yang efektif sebagaimana yang dikemukakan oleh Davies adalah yang dapat mencapai 90 prosen tujuan dari 90 prosen tujuan dari 90 prosen waktu pembelajaran yang disediakan. Prosentase dalam bentuk kriteria 90/90/90 ini tidak hanya menunjukkan pengajaran yang tepat guna akan tetapi juga diikuti dengan pengajaran yang tepat waktu atau pengajaran yang efektif dan efisien. Efektivitas dan efisiensi pembelajaran merupakan pertanyaan yang harus dijawab dalam setiap pembelajaran yang dilakukan. Efektifitas dan efisiensi terkait dengan prinsip mastery learning atau penguasaan pembelajaran. Efisiensi berkaitan dengan melakukan segala sesuatunya dengan benar, sementara itu efektivitas berkaitan dengan melakukan sesuatu yang benar.

Efektifitas dan efisiensi pembelajaran memerlukan penguasaan terhadap segala sesuatu yang berkaitan dengan kelancaran proses belajar mengajar. Untuk itu guru yang efektif memerlukan: (a) pengetahuan tentang konten dan ilmu didik (memahami mata pelajaran dan cara mengajarkannya), (b) pengetahuan tentang siswa (mengetahui bagaimana siswa belajar dan berkembang), (c) kemampuan menyeleksi tujuan pembelajaran (mengembangkan tujuan pembelajaran dengan tepat), (d) pengetahuan tentang sumber belajar (mampu menempatkan materi-materi ajar sesuai dengan siswa yang akan belajar), (e) kemampuan mendisain pembelajaran (dapat membuat perencanaan pembelajaran yang efektif), dan (f) kemampuan dalam mendisain evaluasi belajar siswa (dapat mendisain evaluasi yang adil dan bermakna).
Guru efektif sebagaimana yang dikemukakan di atas hanya mungkin dilakukan apabila perencanaan dan pelaksanaan pembelajaran dapat menemukan teknik pembelajaran yang sesuai. Menurut Moore (2005:09) perencanaan dan teknik pembelajaran guru yang efektif meliputi; (1) berkomunikasi dengan jelas dan akurat (menggunakan keterampilan komunikasi lisan dan tulisan yang kuat), (2) menggunakan pertanyaan efektif dan teknik-teknik diskusi (menggunakan berbagai macam bentuk pertanyaan dan jawaban), (3) menimbulkan minat peserta didik dalam belajar (melibatkan anak secara aktif dalam pembelajaran), (4) memberikan balikan kepada peserta didik (memberikan informasi terhadap perkembangan siswa), dan (5) bersifat fleksibel dan responsive (memodifikasi pembelajaran dengan serta merta berdasarkan umpan balik yang diterima).

Selanjutnya dalam kaitan efektivitas suatu pembelajaran Davies (1981:24) mengemukakan empat keterampilan utama yang harus dimiliki oleh guru yaitu: (1) sensitif, (2) diagnostisian, (3) ahli, dan fleksibel. Pertama, sensitif berarti bahwa guru harus sensitif terhadap kebutuhan tugas-tugas pembelajaran dan sesuai dengan kebutuhan siswa dalam upaya penguasaan tugastugas yang dilakukannya; kedua, diagnostisian yaitu guru mampu menentukan apa yang telah dikuasai siswa dan apa yang harus dilakukan agar tujuan pembelajaran dapat dicapai; ketiga, ahli yaitu guru dapat mementukan metode belajar mengajar yang sesuai dan kemudian gunakan sesuai dengan tujuan yang telah ditentukan bukan karena kebetulan; keempat, yaitu guru cukup fleksibel dalam mengahadapi situasi yang terjadi dan dapat menyesuaikan rencana dengan keadaan yang dihadapi tersebut. Dalam kaitan penguasaan keempat keterampilan utama dalam di atas maka guru harus terfokus pada peluang-peluang yang mungkin dapat ia lakukan tidak hanya terfokus kesulitan-kesulitan yang dihadapinya.

Sehubungan dengan upaya guru untuk membuka peluang-peluang yang mungkin dalam meningkatkan efektivitas pembelajaran tersebut Moore secara cerdas memberikan perumpamaan pembelajaran pada sebuah topi. Menurut Moore (2005:14) guru yang efektif harus fleksibel dan harus mampu memaknai berbagai macam topi. Kadang-kadang topi yang berbeda-beda ini digunakan hanya sesekali sesuai dengan kepentingannya. Fleksibilitas memungkinkan dilakukan percobaan sehingga apabila suatu strategi tidak berjalan dengan baik maka strategi 
yang baru harus dicoba. Seorang guru bukan lagi guru apabila menghitung-hitung jumlah topinya. Seorang guru seharusnya juga dapat memerankan peran orang tua, konselor dan penegak disiplin dalam suatu kesatuan yang utuh.

Fleksibilitas perilaku guru terkait dengan sejauhmana orintasi perilaku guru apakah berorientasi murid atau berorientasi guru. Orientasi perilaku guru disebut Wolgang (1981) Kontinum Perilaku Guru (KPG). Kontinum Perilaku Guru adalah cara pandang guru dalam tindakannya untuk terlibat dalam aktivitas bermain anak. Guru dapat bergerak dalam kontinum terbuka dan terstruktur. Guru dapat mengawali kegiatan anak dengan cara membiarkan anak bermain sendiri tanpa intervensi guru jika guru berpendapat bahwa anak mempunyai kompetensi untuk melakukan kegiatan main tersebut. Sementara itu jika guru menganggap bahwa anak akan menghadapi kesulitan dalam melaksanakan tugasnya guru mulai melakukan intervensi yang bersifat terstruktur. Kegiatan terstruktur ini dapat terbuka kembali apabila guru menilai bahwa kegiatan anak tidak perlu lagi dikontrol secara ketat. Kontinum Perilaku Guru ini mulai dari hanya mengamati visually looking on , pernyataan yang tidak mengarahkan nodirective statement, bertanya questions, pernyataan mengarahkan directive statement, memberikan contoh modelling, dan intervensi fisik physical intervention. KPG ini terjadi dalam semua aktivitas main baik yang menggunakan konstruksi/ bangunan, sensorimotor, bermain simbolik, dan sosiodrama.

Semua itu hanya mungkin dilakukan apabila karakteristik yang kuat sebagai seorang guru. Dalam kaitan karakter guru tersebut Cruickkshank (2006:322) mengemukakan attribut guru yang efektif adalah mempunyai rasa ingin tahu yang kuat, bersifat hangat dan humoris, kredibel, mempunyai harapan yang tinggi terhadap kesuksesan, bersifat supportif, berorientasi tugas, mudah beradaptasi/fleksibel, dan mempunyai pengetahuan. Semua ini menunjukkan bahwa seorang calon guru yang sedang kuliah pada LPTK tidak hanya berorientasi pada ilmu-ilmu keguruan semata tetapi juga harus memperkuat kompetensi yang diperlukan oleh seorang guru.

Menurut Danielson dalam Moore (2005:08) mengemukakan empat keterampilan utama bagi pembelajaran efektif. Guru efektif (1) mengembangkan perencanaan dan persiapan yang berkualitas, (2) mempersiapkan lingkungan kelas yang positif, (3) menggunakan teknik pembelajaran yang sesuai, dan (4) menunjukkan perilaku yang profesional.

\subsubsection{Kualitas Perencanaan dan Persiapan}

Banyak orang yang berasumsi bahwa yang diperlukan bagi seorang guru yang efektif adalah memahami konten yang akan diajarkan. Mereka berasumsi bahwa apabila mereka mengetahui konten, adalah semudah bagaimana ia dapat menceritakan apa yang ia ketahui. Dalam kenyataannya mata pelajaran merupakan salah satu bagian dari proses belajar mengajar. Guru yang efektif harus menggunakan waktu dan energinya dalam merencanakan aktivitas, materi, dan evaluasi yang berkaitan dengan konten pembelajaran. Untuk itu Danielson menemukan bahwa guru yang efektif memerlukan: (1) pengetahuan konten dan ilmu didik (mengetahui mata ajar dan mengetahui bagaimana mengajarkannya), (2) pengetahuan tentang anak (mengetahui bagaimana anak belajar dan berkembang), (3) kemampuan menyeleksi tujuan pembelajaran (mengembangkan hal yang diharapkan), (4) pengetahuan tentang sumber belajar (dapat menempatkan materi ajar dan sumber belajar yang dapat meningkatkan pembelajaran), (5) kemampuan mendisain pembelajaran (dapat merencanakan perencanaan pembelajaran yang efektif), (6) kemampuan mendisain evaluasi anak (dapat mendisain evaluasi yang adil dan bermakna)

\subsubsection{Mempersiapkan Lingkungan Kelas yang Positif}

Pengertian lingkungan kelas dikemukan oleh Loudursamy (2005:4) bahwa kelas adalah suatu tempat dimana guru dan murid berintekraksi satu sama lain dalam proses belajar mengajar untuk membangun pengetahuan dari informasi yang tersedia. Aktivitas di kelas yang melibatkan guru dalam mengkomunikasikan tujuan untuk anak, mengatur aktivitas pembelajaran, memonitor perkembangan kemajuan anak, memotivasi anak untuk belajar, mendorong anak berpikir kritis dan kreatif, berinteraksi dengan guru dan murid lainnya, memberikan pertolongan dan memberikan feedback.

Guru yang efektif harus menciptakan dan mempertahankan lingkungan sehingga pembelajaran dapat terjadi. Danielson dalam Moore (2005:09) menemukan bahwa perencanaan lingkungan kelas yang dapat menumbuhkan pengalaman yang positif memerlukan keterampilan pada: (a) menciptakan suatu lingkungan yang menghargai dan menumbuhkan rasa positif 
(menjadi guru yang peduli pada anak dan hubungan sesama anak), (2) mengembangkan suatu budaya bagi belajar (menciptakan lingkungan yang menghargai belajar sebagai sesuatu yang bernilai dan pengalaman bermakna dapat terjadi), (3) mengelola kelas (kesuksesan dalam mengelola aktivitas kelas), (4) mengelola perilaku anak (respon yang efektif terhadap perilaku anak yang sesuai maupun yang tidak sesuai), (5) mengorganisasikan lingkungan fisik (penggunaan ruang kelas yang positif).

Peran guru dalam pembelajaran merupakan hal yang mendasar dalam pembelajaran siswa. Oleh sebab itu filosofi merupakan daya dorong bagi guru untuk memainkan perannya dalam proses pendidikan. Masing-masing filosofi mengembangkan kurikulum pembelajaran menunjukkan peran guru sesuai dengan filosofinya tentang anak. Menurut Roopnarine (2005: 04-14) secara beturutturut menjelaskan peran guru dari masa ke masa. Pada abad ke-18 di sekolah kolonial pendekatan guru bersifat individual, pembelajaran kelompok jarang dilakukan. Pembelajaran bersifat mengingat bacaan dan duduk manis di meja. Hukuman seringkali digunakan dalam proses belajar mengajar. Pada abad ke-19 peran guru ditunjukkan dalam bentuk hubungan antara guru dan murid dengan membangun kurikulum bersama-sama. Keberlanjutan hubungan ibu dan anak yang penuh kecintaan merupakan inti dalam pengembangan kurikulum di luar rumah sehingga tingkat kesiapan anak merupakan landasan dalam pengembangan pengalaman belajar anak. Pada abad ke-20 peran guru pada pendidikan anak usia dini adalah mengarahkan dan manager pentas. Anak bermain secara spontanitas dan minat anak dari luar sekolah di obervasi oleh guru, kemudian atas dasar tersebut kurikulum dikembangkan.

Spektrum manajemen kontrol menurut Scarpaci (2007:54) bergerak antara kontinum berorientasi guru sampai dengan berorientasi siswa dan mulai dari konsekuensi panduan berkelompok sampai dengan panduan bersifat perorangan/individual. Pertama, autoritarian yaitu guru melaksanakan kontrol lebih dominan dengan menetapkan aturanaturan untuk mempertahankan kontrolnya. Kedua, moderat yaitu fokus utama pada orientasi siswa agar berperilaku sesuai dengan harapan guru. Disiplin dikembangkan dalam bentuk kerjasama kelompok atau kelas dengan batasan-batasan tertentu. Ketiga, sedikit kontrol yaitu bersifat toleran dan permisif sehingga fokus pada memaksimalkan kebebasan siswa. Guru tidak berperan menginterfensi tetapi membiarkan siswa berekspresi dengan bebas.

Spektrum manajemen kelas tersebut menurut Cooper dalam Scarpaci (2007:53) dapat digambarkan sebagai empat tahapan proses yaitu guru (1) menetapkan kondisi yang diharapkan, (2) menganalisasi kondisi yang ada, (3) menggunakan strategi manajemen, dan (4) mengukur efektivitas. Manajemen dapat dipandang dari perspektif yaitu konsekuensi yang disebabkan oleh guru dan yang lainnya terfokus kepada panduan bersifat individual untuk membuat pilihannya.

\subsubsection{Menggunakan Teknik Pembelajaran yang Sesuai}

Hasil dari pengembangan kurikulum yang terencana dengan baik adalah suatu program yang kaya dengan pengalaman yang sesuai. Pengalaman yang di kembangkan pada anak pra sekolah selalu dikaitkan dengan aktivitas-aktivitas. Interasi antara guru dan murid tercipta dalam suatu realitas yang berlandaskan aktivitas merupakan bagian nyata dari kurikulum. Menurut Arce (200:04) variasi aktivitas dikenal dengan "hands-on" yang berarti anak menggunakan tangan, lengan, kaki, dan badan tidak hanya sekedar menyimak dan mengobservasi. Pengertian aktivitas lain adalah "konkrit" yaitu menggambarkan aktivitas yang memungkinkan anak menggunakan materi-materi yang sesungguhnya dan berpartisipasi secara aktif.

Teknik pembelajaran harus terencana sehingga dapat menumbuhkan minat anak dan memotivasi mereka untuk belajar. Teknik-teknik yang digunakan dalam pembelajaran meliputi bertanya, menggunakan ide-ide dan kontribusi anak, dan memperkuat. Danielson dalam Moore (2005:9-10) menemukan bahwa guru yang efektif dalam perencanaan dan menggunakan teknik instruksional bahwa: (1) berkomunikasi dengan jelas dan akurat (menggunakan keterampilan komunikasi verbal dan tertulis yang kuat), (2) menggunakan teknik bertanya dan diskusi yang efektif (menggunakan berbagai bentuk pertanyaan dan respon), (3) anak terlibat dalam belajar (anak terlibat secara aktif dalam belajar), (4) memberikan fedback pada anak (memberikan informasi atas perkembangan atau kemajuan anak) dan (5) bersifat fleksibel dan responsif.

\subsubsection{Menunjukkan Perilaku yang Profesional.}

Pembelajaran seringkali melampaui batas-batas pembelajaran tradisional. Guru yang efektif selalu berupaya dengan keras meningkatkan pengetahuan 
dan keterampilannya dalam pembelajaran sehingga pekerjaan yang dilakukannya dapat memberikan kontribusi pada sekolah dan masyarakat sekitar. Mereka benar-benar bekerja secara profesional. Danielson dalam Moore (2005:10) mengemukakan bahwa guru yang bebar-benar profesional: (1) melakukan refleksi terhadap pembelajarannya (melakukan pertimbangan yang matang tentang apa yang diajarkan dan bagaimana mengajarkannya), (2) membuat pencatatan yang akurat (membuat dan menyimpan catatan tentang dokumen pembelajaran anak), (3) melakukan komunikasi dengan keluarga anak (melakukan hubungan secara tertulis dan lisan dengan keluarga anak tentang perkembangan kemajuan anak), (4) berkontribusi terhadap sekolah dan pemerintah daerah (mendukung fungsi sekolah dan pemerintah daerah), dan (5) bertumbuh secara profesional (mengikuti kursus, workshop dan berkonsultasi dengan sejawat), dan (6) menunjukkan profesionalisme (melakukan pelayanan sebagai advokasi bagi anak dan keluarga).

\subsection{Kajian riset sebelumnya}

Hasil penelitian menunjukkan bahwa sebagian besar guru mengajar dengan cara bagiamana ia diajar pada saat belajar. Umumnya guru tidak mengajar sesuai dengan cara mengajar yang dia pelajari. Kenyataan ini sangat mengkawatirkan bahwa pendidikan, pelatihan tidak akan berpengaruh banyak pada cara guru mengajar kecuali mengajar sesuai dengan cara-cara umum orang belajar. Untuk itu perlu dipelajari apakah pengalaman berbeda dan pendidikan yang sama menghasilkan cara yang berbeda kepada mahasiswa PAUD.

\section{METODOLOGI PENELITIAN}

Penelitian ini bersifat deskriptif analitik, yaitu data dideskripsikan dengan menggunakan statistik deskriptif, dan dimaknai secara mendalam berdasarkan perspektif emik yaitu penyajian data secara alamiah tanpa melakukan suatu manipulasi atau perlakuan terhadap subjek yang diteliti (Bogdan dan Taylor, 1975:31). Disamping itu data deskriptif yang diisi oleh pengurus dan pendidik PAUD diperkuat melalui triangulasi data melalui observasi dan wawancara pada pengurus dan pendidik PAUD, orang tua, dan masyarakat sekitar sekolah.

\subsection{Tempat dan Waktu Penelitian}

Penelitian dilaksanakan di Program Studi Pendidikan Anak Usia Dini Universitas Al Azhar Indonesia yang diklasifikasikan sebagai mahasiswa murni dan mahasiswa yang telah mengajar di PAUD atau Taman Kanak-Kanak. Sedangkan waktu penelitian berlangsung selama 9 (sembilan) bulan, yaitu dari bulan Maret 2011 - Nopember 2011.

\subsection{Ruang Lingkup dan Objek penelitian}

Ruang lingkup dan objek penelitian meliputi halhal sebagai berikut:

a. Wilayah penelitian dibatasi pada PAUD Universitas Al Azhar Indonesia

b. Sasaran Penelitian adalah mahasiswa PAUD angkatan Semester 4 ke atas Prodi PAUD Universitas Al Azhar Indonesia.

c. Penelitian hanya mengkaji mahasiswa PAUD Universitas Al Azhar Indonesia baik mahasiswa murni maupun mahasiswa yang telah bekerja.

\subsection{Alat Pengumpul Data}

Alat pengumpulan data yang digunakan dalam penelitian ini adalah angket yang dimaksudkan untuk mengetahui persepsi mahasiswa, observasi, wawancara yang digunakan untuk triangulasi data angket (angket terlampir).

\subsection{Pengolahan dan Analisis Data}

Berdasarkan data primer dan data sekunder yang diperoleh, maka pengolahan data selanjutnya diolah dan dianalisis dengan menggunakan analisis:

1. Analisis Statistik Deskriptif: data angket yang diisi oleh responden dianalisis dengan statistik deskriptif guna melihat kecenderungan data tentang persepsi responden.

2. Analisis Kualitatif: data hasil analisis statistik deskriptif selanjutnya dijelaskan secara kualitatif melalui hasil deskripsi observasi dan wawancara dengan responden. 


\section{HASIL PENELITIAN}

Sesuai dengan pertanyaan penelitian yang dikemukakan pada Bab I sebelumnya bahwa penelitian ini berupaya untuk mengetahui: (1) perbedaan persepsi mahasiswa murni dan mahasiswa bekerja terhadap pendekatan pembelajaran, (2) perbedaan persepsi mahasiswa murni dan mahasiswa bekerja terhadap praktek pembelajaran, dan (3) faktor yang melatarbelakangi perbedaan persepsi mahasiswa murni dan mahasiswa bekerja terhadap pembelajaran di PAUD.

\subsection{Mengembangkan Perencanaan dan Persiapan yang Berkualitas}

Secara keseluruhan respon yang dikemukakan oleh mahasiswa non guru terhadap aspek pengembangan perencanaan dan persiapan yang berkualitas lebih rendah dari mahasiswa yang telah menjadi guru. Pengembangan perencanaan dan persiapan yang berkualitas meliputi (1) pengetahuan konten dan ilmu didik (mengetahui mata ajar dan mengetahui bagaimana mengajarkannya), (2) pengetahuan tentang anak (mengetahui bagaimana anak belajar dan berkembang), (3) kemampuan menyeleksi tujuan pembelajaran (mengembangkan hal yang diharapkan), (4) pengetahuan tentang sumber belajar (dapat menempatkan materi ajar dan sumber belajar yang dapat meningkatkan pembelajaran), (5) kemampuan mendisain pembelajaran (dapat merencanakan perencanaan pembelajaran yang efektif), (6) kemampuan mendisain evaluasi anak (dapat mendisain evaluasi yang adil dan bermakna).

Dalam kegiatan pengembangan perencanaan dan persiapan pembelajaran terlihat bahwa ada perbedaan antara idealitas mahasiswa non guru (NG) dengan realitas yang dihadapi oleh guru (G) yang mempunyai pengalaman berhadapan dengan murid dilapangan. Kenyataan ini ditunjukkan oleh pernyataan guru yang menganggap bahwa persiapan secara lebih rinci lebih penting jika dibandingkan oleh jawaban non guru (no.2), namun demikian fleksibilitas perencanaan juga perlu diperhatikan dalam kaitannya dengan perhatian anak (no.15). Sebagian besar jawaban mahasiswa yang telah menjadi guru atau yang telah mengajar lebih bersifat situasional dalam melihat realitas di kelas. Kenyataan pengembangan pembelajaran sesuai dengan realitas ini dapat dilihat dari jawaban yang dikemukan tentang pentingnya memberi kesempatan kepada anak untuk berekplorasi, kegiatan yang dikembangkan atas dasar kebermaknaan bagi anak. Kenyataan lainnya juga dapat dilihat dalam pengembangan evaluasi dalam perencanaan pembelajaran.

Perbedaan yang sangat mencolok antara non guru dan guru adalah mahasiswa non guru lebih menunjukkan keberanian membuat tujuan pembelajaran pada saat proses pembelajaran dilaksanakan. Hal yang sama juga diperlihatkan dalam persiapan urutan pembelajaran yang tidak perlu terinci sebagaimana yang dikemukakan oleh guru. Disisi lain mahasiswa yang berlatar belakang guru lebih terkesan hati-hati dalam menjawab pertanyaan (no.7) karena konsekuensi pembuatan tujuan yang bersifat serta merta memerlukan kemampuan dalam mengembangkan pembelajaran.

\subsection{Mempersiapkan Lingkungan Kelas yang Positif}

Secara keseluruhan respon mahasiswa yang telah menjadi guru menunjukkan bahwa mempersiapkan kelas yang positif sangat diperlukan jika dibandingkan dengan respon mahasiswa murni. Perencanaan lingkungan kelas yang dapat menumbuhkan pengalaman yang positif memerlukan keterampilan pada: (a) menciptakan suatu lingkungan yang menghargai dan menumbuhkan rasa positif (menjadi guru yang peduli pada anak dan hubungan sesama anak), (2) mengembangkan suatu budaya bagi belajar (menciptakan lingkungan yang menghargai belajar sebagai sesuatu yang bernilai dan pengalaman bermakna dapat terjadi), (3) mengelola kelas (kesuksesan dalam mengelola aktivitas kelas), (4) mengelola perilaku anak (respon yang efektif terhadap perilaku anak yang sesuai maupun yang tidak sesuai), (5) mengorganisasikan lingkungan fisik (penggunaan ruang kelas yang positif).

Hasil penelitian menunjukan bahwa untuk meningkatkan lingkungan yang positif bagi anak diperlukan hal sebagai berikut:

1. Menumbuhkan lingkungan yang positif pada anak perlu melibatkan setiap orang yang berinteraksi dengan anak baik guru, orang tua, murid dan tenaga administrator lainnya.

2. Budaya belajar yang berorientasi proses merupakan inti dari suatu pembelajaran bagi anak usia dini. Untuk itu anak harus benarbenar terlibat dalam suatu aktivitas yang nyata dan melibatkan seluruh inderanya.

3. Produk belajar atau hasil karya merupakan tujuan utama dari setiap pembelajaran anak 
usia dini, karenanya penghargaan terhadap hasil karya anak merupakan bagian penting dalam meningkatkan produktifitas anak.

4. Sebagai salah satu tujuan pembelajaran anak usia dini adalah penanaman kebiasaan oleh sebab itu mahasiwa memandang bahwa semua kesalahan yang dilakukan anak harus sesegera mungkin diperbaiki. Kesegeraan ini terkait dengan pembiasaan yang benar dan agar tidak menimbulkan kesalahan yang lebih besar.

5. Dalam pembiasaan diperlukan kesadaran untuk menerima semua akibat yang dilakukan anak oleh sebab itu anak harus mengetahui konsekuensi yang akan diterima atas segala tindakannya.

6. Semua konsekuensi yang akan diterima anak perlu dimonitor oleh guru dan oleh sebab itu pula maka dalam menanamkan disiplin kepada anak perlu dimonitor dengan ketat.

7. Disisi lain konsekuensi yang akan dijalani anak harus mempertimbangkan usia dan dapat meimbulkan penerimaan positif dari anak. Dalam kaitan itu maka pemberian hukuman kepada anak harus disesuaikan dengan kondisi anak tersebut.

8. Pembelajaran klasikal yang beorientasi pada aktivitas yang didominasi oleh guru bukanlah merupakan cara yang tepat bagi anak usia dini. Anak usia dini memerlukan ekplorasi dan oleh sebab itu diperlukan penataan ruang memberikan keleluasaan anak dalam beraktivitas sehari-hari.

\subsection{Menggunakan Teknik Pembelajaran yang Sesuai}

Menemukan bahwa guru yang efektif dalam perencanaan dan menggunakan teknik instruksional bahwa: (1) berkomunikasi dengan jelas dan akurat (menggunakan keterampilan komunikasi verbal dan tertulis yang kuat), (2) menggunakan teknik bertanya dan diskusi yang efektif (menggunakan berbagai bentuk pertanyaan dan respon), (3) anak terlibat dalam belajar (anak terlibat secara aktif dalam belajar), (4) memberikan fedback pada anak (memberikan informasi atas perkembagan atau kemajuan anak) dan (5) bersifat fleksibel dan responsif. Respon yang dikemukakan oleh mahasiswa antara lain:

1. Cara bertanya yang tepat sama pentingnya dengan cara menjawab pertanyaan anak

2. Berdiskusi dengan anak perlu dilakukan untuk menggali informasi yang dimiliki anak
3. Seiring dengan berjalannya waktu anak dengan sendirinya akan mengetahui kelebihan dan kekurangan hasil pekerjaannya

4. Konsistensi pemberian feedback atas karya anak perlu dilakukan oleh orang tua

5. Setiap anak bersifat unik karena itu guru bersifat fleksibel dalam menentukan standar pembelajaran bagi anak

6. Fleksibilitas terhadap anak harus diikuti dengan sikap guru yang responsif.

\subsection{Menunjukkan Perilaku yang Profesional.}

Untuk mengetahui persepsi mahasiswa tentang penunjukkan perilaku profesional dapat diketahui melalui (1) melakukan refleksi terhadap pembelajarannya (melakukan pertimbangan yang matang tentang apa yang diajarkan dan bagaimana mengajarkannya), (2) membuat pencatatan yang akurat (membuat dan menyimpan catatan tentang dokumen pembelajaran anak), (3) melakukan komunikasi dengan keluarga anak (melakukan hubungan secara tertulis dan lisan dengan keluarga anak tentang perkembangan kemajuan anak), (4) berkontribusi terhadap sekolah dan pemerintah daerah (mendukung fungsi sekolah dan pemerintah daerah), dan (5) bertumbuh secara profesional (mengikuti kursus, workshop dan berkonsultasi dengan sejawat), dan (6) menunjukkan profesionalisme (melakukan pelayanan sebagai advokasi bagi anak dan keluarga).

Sebagaimana yang ditemukan pada bagian sebelumnya diketahui bahwa rata-rata persepsi mahasiswa yang berasal dari guru lebih tinggi daripada mahasiswa yang belum menjadi guru atau mahasiswa murni. Hal ini antara lain dipengaruhi oleh tuntutan profesi guru di sekolah yang tentunya belum dialami oleh mahasiswa murni. Ada beberapa hal yang dapat dikemukan dalam pengembangan profesional guru ini yaitu antara lain.

1. Menurut mahasiswa yang berlatar belakang guru, catatan yang akurat tentang perkembangan tidak hanya diperlukan untuk laporan kepada kepala sekolah tetapi juga kepada orang tua dan pihak-pihak yang memerlukannya.

2. Umumnya guru berpendapat bahwa kursus yang dilakukan guru seringkali tidak didayagunakan karena itu kursus bagi guru tidak begitu penting. Pengalaman menunjukkan bahwa sikap dan perilaku guru dalam mengajar sangat ditentukan oleh kebiasaan sekolah masing-masing. Ada sekolah yang cepat 
menerima perubahan dan ada pula sekolah yang perubahannya lebih ditentukan oleh kemauan kepala sekolah atau manajemen sekolah. Kenyataan ini juga menentukan efektivitas kursus, latihan, seminar atau workshop.

3. Guru menganggap bahwa perolehan informasi dari orang tua tentang riwayat perkembangan anak sangat penting bagi proses pembelajaran anak di sekolah. Keterbatasan pengetahuan guru terhadap murid mereka anggap dapat mengurangi kualitas pelayanan guru terhadap murid dengan secara tepat.

4. Menurut guru tugas mereka tidak hanya mengajar di kelas dan oleh sebab itu advokasi pada keluarga anak merupakan bagian dari tugas guru PAUD

5. Penambahan pengetahuan baru dari berbagai sumber perlu dilakukan oleh guru PAUD

Dari uraian di atas dapat diketahui bahwa perbedaan persepsi mahasiswa murni dan mahasiswa bekerja terhadap pendekatan pembelajaran tidak jauh berbeda, kecuali karena faktor pengalaman di lapangan sehingga penjelasan guru lebih bersifat aplikatif. Perbedaan persepsi mahasiswa murni dan mahasiswa bekerja terhadap praktek pembelajaran dilatar belakangi oleh wawasan guru yang telah terbangun melalui praktek sehari-hari disekolah. Sedangkan faktor yang melatar belakangi perbedaan persepsi mahasiswa murni dan mahasiswa bekerja terhadap pembelajaran di PAUD juga disebabkan oleh budaya masing-masing sekolah dalam penerima suatu pembaruan.

\section{KESIMPULAN DAN SARAN}

\subsection{KESIMPULAN}

Berdasarkan hasil penelitian yang dikemukan pada Bab IV maka dapat dismpulkan bahwa :

1. Secara keseluruhan mahasiswa mempunyai pandangan positif terhadap semua bentuk pendekatan yang digunakan dalam pembelajaran anak usia dini. Hal ini ditunjukkan oleh penerimaan mahasiswa terhadap pendekatan sesuai dengan kondisi yang dihadapi dalam pembelajaran.

2. Perbedaan persepsi teori-teori belajar yang dipelajari oleh mahasiswa lebih ditentukan oleh pengalaman praktis guru di dalam proses belajar mengajar. Untuk itu pengalaman lapangan sangat penting dalam membuka wawasan mahasiswa tidak hanya dari sudut teori akan tetapi juga kenyataan di lapangan.

3. Faktor yang melatar belakangi perbedaan persepsi mahasiswa murni dan mahasiswa bekerja terhadap pembelajaran di PAUD juga disebabkan oleh budaya organisasi masingmasing sekolah.

\subsection{SARAN}

Berdasarkan hasil penelitian dan kesimpulan yang dikemukakan sebelumnya maka dapat disarankan hal sebagai berikut:

1. Penanaman keyakinan mahasiswa terhadap efektivitas masing-masing pendekatan pembelajaran perlu diperkuat dengan pengalaman praktis yang lebih memadai dalam pembelajaran.

2. Komunikasi antara mahasiswa murni dan guru agar lebih intensif dalam proses pembelajaran di kelas sehingga pengalaman guru dapat membelajarkan mahasiswa murni.

3. Mahasiwa murni dan guru perlu pengalaman yang lebih bervariasi baik dalam proses penitipan anak, satuan PAUD sejenis, kelompok bermain, Taman Kanak-kanak maupun SD awal guna memperkaya pengalaman dari berbagai tahapan usia anak.

\section{DAFTAR PUSTAKA}

[1] Arce, Eve-Marie, Curriculum for Young Children: An Introduction, New York: Delmar Thomson Learning, 200.

[2] Cruickshank, Donald R., Deborah Bainer Jenkins dan Kim K. Metcalf, The Act of Teaching Fourth Edition, Boston: McGraw Hill Higher Education, 2006.

[3] Davies, Ivor K., Instructional Technique, Washington DC.:McGraw-Hill, 1981.

[4] Dodge, Dianne Trister, Laura J. Colker dan Cate Heroman, The Creative Curriculum for Preschool, Fourth Edition Washington: Teaching Strategic Inc., 2002.

[5] Leng, Yeap Lay, "Repertoire of Knowledge and Skill for Effective Teaching" Classrom Management : Facilitating Teaching and Learning Edited by Myint Swe Khine dkk., Singapore: Pearson Prentice Hall, 2005

[6] Lodursamy, A., "Establishing a Conducive Learning Environment" Classroom Management: Facilitating Teaching and Learning Edited by Myint Swe Khine dkk, Singapore: Pearson Prentice Hall, 2005. 
[7] Moore, Kenneth D., Effective Instructional Strategies: From Theory to Practice California: Sage Publication Inc., 2005.

[8] Neisworth, John T., "Behavior Analysis and Principles in Early Childhood Education" Apparoach to Early Childhood Education Fourth Edition New Jersey: Pearson Merill Prentice Hall, 2005.

[9] Reigeluth, Charles M., dan Alison A. CarrrCellman, "Understanding Instructional Theory" Instructional-Design Theories and Models Volume III: Building a Common Knowledge Base editor
Charles M. Regeluth dan Alison A. Carr-Chellman, New York: Routledge, 2009.

[10] Roopnarine, Jaipul L., dan James E Johnson, Approach to Early Childhood Education Fourth Edition New Jersey: Pearson Meril Prentice Hall, 2005.

[11] Wolgang, Charle H., Bea Mackender dan Mary E. Wolgang, Growing and Learning through Play: Activities for Preschool and KindergartenChildren A Parent/Caregiver Book, USA:Judi/Instructo, 1981. 